\title{
サクラマスの脂質一III
}

降海時期における河川残留型およぴ降海型サクラマス 幼魚の脂質組成の相異*1

\author{
太田亨・山田実
}

(1974 年 5 月 17 日受理)

\section{Lipids of Masu Salmon-III}

\section{Differences in the Lipids of Residual Type and Seaward Migration Type of Masu Salmon Parr during the Period of Seaward Migration}

Tōru ŌTA*2 and Minoru YAMADA ${ }^{* 2}$

\begin{abstract}
Differences in the lipid compositions and the fatty acid compositions of the residual type and seaward migration type of Masu salmon parr (Oncorhynchus masou) fiesh lipids during the period of seaward migration were investigated.

The results obtained are summarized as follows:

1) The lipid content of the seaward migration type was less than one-half that of the residual type.

2) Comparison of the residual type and seaward migration type lipid compositions indicated a lower content of triglycerides and higher contents of phospholipids and free sterols in the seaward migration type.

3) The contents of each fatty acid were uniformly lower in the seaward migration type than in the residual type, the decrease in palmitoleic and oleic acids being more conspicuous in the seaward migration type.

It was considered that the consumption of lipids (mainly triglycerides) as the energy source in the seaward migration type swelled during the period of seaward migration and that, among the fatty acids, the monoenoic acids might be chiefly consumed. Furthermore, the consumption of polyenoic acids as well as saturated and monoenoic acids might increase during the latter stage of smolt-transformation.
\end{abstract}

河川で生活するサクラマス幼魚 (Oncorhynchus masou) の中で降海型のサクラマス幼魚が春に变態（スモ ルト化して隆海移動をおこなう䟢には，脂貿も移動のためのエネルギー源として消費されると思われ，そ の結果脂質成分にも変化のあることが考えられるが，この点については前報”で㝨殖サタラ、ス动魚を試料 として变態時期の脂質含量之脂肪酸組成の变動を謂心゙，变態の進行にともない筋肉中の脂留含量方減少し， また脂肪酸では 16:0１8:1が主に減少することをあさらかにした。さらに天然サクラマス纤魚の筋肉脂質 の周年にわたる变動を調へ，河川残留型と降海型とでは脂質含量や脂肪酸組成の変動に相䨢があり，その中 で春では河川残留型の脂質含量が增大寸るのに対し降海型は逆に減少する㑯向を示すなど，羝殖サクラマス 幼魚における結果とぼ恬同樣な脂質の变動の傾向があることを報告した2。

しかし降海時期におけるサクラ、ス幼魚の脂犋の梦化についてはたんに脂䆬含量や脂肪酸組成だけでなく 脂質組成なども詳しく調べ考察する必要があると思われるので, 本報で天然和よび養殖サクラマス幼魚を

*1 北海道大学水産学部七飯養魚実習施設業繢第 4 号

*2 北海道大学水産学部 (Faculty of Fisheries, Hokkaido University, Hakodate, Japan) 


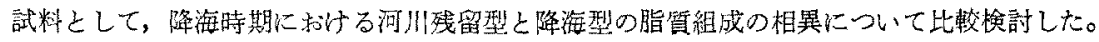

実 瑍 方 法

試料魚寒験以すらいた河川残留型 (Residual type) 扰よび降海型 (Seaward migration type)サクラマ

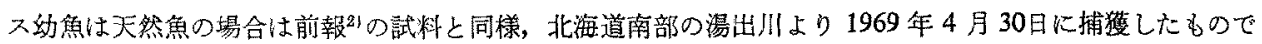

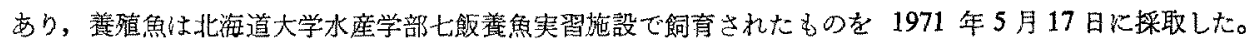
試料魚の体長，体重を Table 1 に示した。

Table 1. Body length, body weight and lipid content of the flesh of Masu salmon parr

\begin{tabular}{|c|c|c|c|c|c|}
\hline Type & Sex* & $\begin{array}{c}\text { Body length } \\
\mathrm{cm}\end{array}$ & $\begin{array}{c}\text { Body weight } \\
\text { g }\end{array}$ & \multicolumn{2}{|c|}{$\begin{array}{c}\text { Lipid content } \\
\%\end{array}$} \\
\hline \multicolumn{5}{|c|}{ Wild fish } & (Average) \\
\hline \multirow{2}{*}{ Residual type } & $\mathbf{M}$ & 12.9 & 37.5 & 4.1 & \multirow{2}{*}{$(4.2)$} \\
\hline & M & 14.7 & 52.2 & 4.3 & \\
\hline \multirow{3}{*}{ Seaward migration type } & $\mathbf{M}$ & 12.0 & 25.7 & 1.3 & \multirow{3}{*}{$(1.9)$} \\
\hline & $F$ & 13.5 & 36.3 & 2.3 & \\
\hline & $F$ & 14.2 & 39.2 & 2.2 & \\
\hline \multicolumn{6}{|c|}{ Cultivated fish } \\
\hline \multirow{4}{*}{ Residual type } & $\mathbf{M}$ & 11.0 & 15.8 & 2.2 & \multirow{4}{*}{$(3.1)$} \\
\hline & $\mathbf{M}$ & 12.2 & 28.8 & 2.9 & \\
\hline & M & 12.6 & 30.7 & 3.2 & \\
\hline & $\mathbf{M}$ & 15.0 & 60.5 & 4.1 & \\
\hline \multirow{3}{*}{ Seaward migration type } & $F$ & 12.6 & 26.3 & 1.4 & \multirow{3}{*}{$(1.4)$} \\
\hline & F & 13.5 & 34.0 & 1.5 & \\
\hline & $\mathrm{F}$ & 13.8 & 36.8 & 1.3 & \\
\hline
\end{tabular}

\footnotetext{
* M-Male, F-Female
}

カラムクロマトグラフィー (CC) 試料魚の筋肉部より BLIGH and DYER 法"31 で抽出した総脂筫をケイ

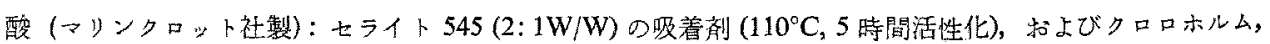
メタノールなどの溶剤をももいクロマトグラフィーをおこない中性脂質とりン脂質とに分画しだ。

中性脂質の CC は吸着剂としてケイ酸（関東化学社製，試料炡し 120 倍量， $110^{\circ} \mathrm{C}, 5$ 時間活性化)を使

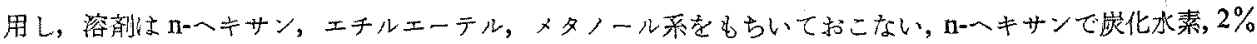

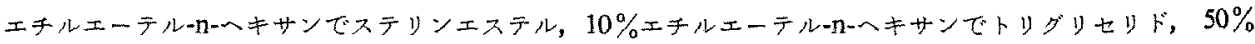
エチルエーテルーローーキサンでジグリセリド，遊離ステリン，25\%×タノールーエチルエーテルで遊離脂肪酸 などの各成分を溶出させだ。な执 CCで完全に分画されない区分についてはさらに薄圈クロマトグラフィ

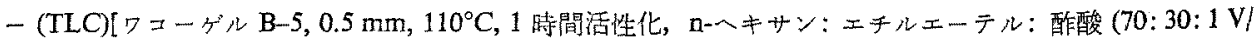

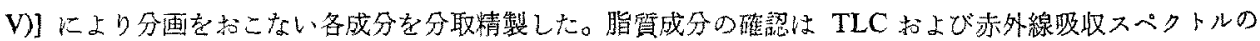
湘定（クロロホルム溶液法）などでおこなった。

カスクロマトクラフィー (GLC) 各脂質成分中の脂肪酸はジン゙メタンでメチルエステル化したのb, 柳本製がスクロマトダラフ G 8FP 型 (水素炎イホン化検出器村) を使用し，10\% DEGSカラム(クロモゾ

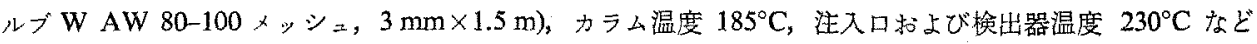

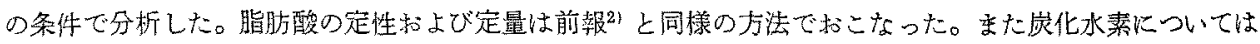
$2 \%$ Silicone OV-17 カラ゙ム (クロモゾルブW AW DMCS 80-100×ッシュ，3 $\mathrm{mm} \times 75 \mathrm{~cm}$ ), カラム温度

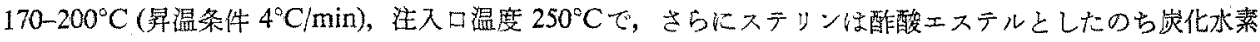
の場合と同じカラムを便用し，カラム湜度 $240^{\circ} \mathrm{C}$ ，注入口温度 $270^{\circ} \mathrm{C}$ C分析した。成分ピークの確認は摽準 物上の比较でおこなった。 


\section{結果および考察}

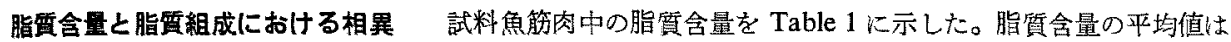
河川残留型に扑いて天然魚 $4.2 \%$ ，養殖魚 $3.1 \%$ であるのに対し，降海型恃天然魚 $1.9 \%$ ，養殖魚 $1.4 \%$ と降

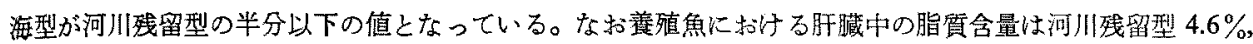
降海型 3.4\% と筋肉の場合注ど顕著ではないが降海型ですくない傾向が認められた。

Table 2. Lipid composition in the flesh of Masu salmon parr (as \% total lipids)

\begin{tabular}{lrrrr}
\hline \multicolumn{1}{c}{ Lipid class } & \multicolumn{2}{c}{ Wild fish } & \multicolumn{2}{c}{ Cultivated fish } \\
& \multicolumn{1}{c}{$\mathbf{R}^{*}$} & \multicolumn{1}{c}{$\mathbf{S}^{*}$} & 0.1 & 0.1 \\
\hline Hydrocarbons & $\mathbf{0 . 4}$ & 0.8 & 0.4 & 0.4 \\
Steryl esters & 0.9 & 0.7 & 64.3 & 20.9 \\
Triglycerides & 75.4 & 58.9 & 1.6 & 2.6 \\
Diglycerides & 2.5 & 2.7 & 4.3 & 4.1 \\
Free fatty acids & 0.8 & 6.1 & 2.0 & 5.1 \\
Sterols & 3.8 & 5.6 & 26.7 & 66.2 \\
Phospholipids & 16.1 & 25.5 & & \\
\hline
\end{tabular}

* R-Residual type, S-Seaward migration type

各試料魚の脂質組成を Table 2 に示した。河川残留型と降海型の脂質組成における大きな相異はトリグリ セリドとリン脂貿の含量にみられる。すなわち、トリグリセリド量は河川残留型に比し降海型ですくなく, とくに養殖魚においてその差が大きく降海型は河川残留型の $1 / 3$ であった。

しかしリン脂質量は逆に降海型の方が多く，また逰離ステリン量も同様であった。

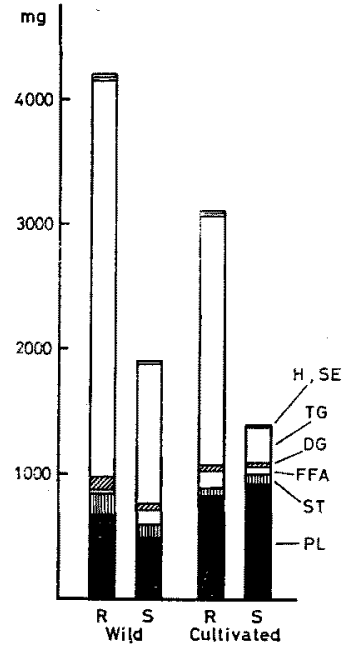

Fig. 1. Lipid composition of the flesh of Masu salmon parr (mg/100 $\mathrm{g}$ of flesh).

$\mathrm{R}$-Residual type, S-Seaward migration type, H-Hydrocarbons, SE-Steryl esters, TG--Triglycerides, DG-Diglycerides, FFA-Free fatty acids, STSterols, PL-Phospholipids
脂質合量と脂質組成比から筋肉中に桝子る各脂質成分 の量を筋肉 $100 \mathrm{~g}$ 中の $\mathrm{mg}$ 数としてあらわした場合の河 川残留型と降海型の相異をFig. 1 に示した。天然魚降海 型のトリグリセりド量は筋肉 $100 \mathrm{~g}$ 中 $1120 \mathrm{mg}$ で河川残 留型 $3170 \mathrm{mg}$ の $35 \%$ なた着殖魚では降海型が $290 \mathrm{mg}$ で河川残留型 $1990 \mathrm{mg}$ の $15 \%$ であった。これに対し リン脂質量は，天然魚では河川残留型 $680 \mathrm{mg}$, 降海

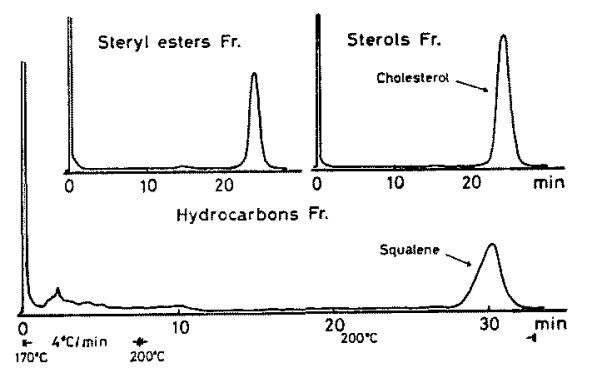

Fig. 2. Gas-liquid chromatograms of hydrocarbons and steryl acetates in the flesh lipids of wild Masu salmon parr (Residual type). 


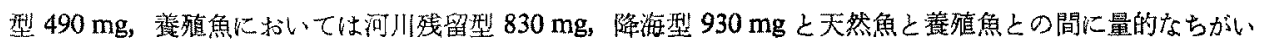
はあるが河川残留型と降海型との差はあまり大きくなく，また型による一蠳した傾向も認められない。リン 脂質が細胞膜の主要構成成分であることを考えると愿の組織中では生物学的な变化(変龍)にあるり影䭚を受 けず量的にほぼ一定の值を示すものと考兵られる。

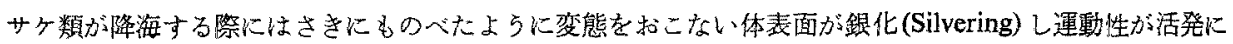
なるが，この上うな変化と甲状腺ホルもンとは密接に関連することが知られている6゙。TAKASHIMA ら゙は はニ ジマス汇数種のホルモンを投与して血墏中の脂質やリポ蛋白質の变動を調べ，甲状腺末を投与したニジマス で脂質やリポ蛋白質の含量が低下することをあきらかにした。このよらなことから降海型サクラマス幼魚 に淤ける筋肉中の脂質含量やトリグリセりド量が河川残留型に比しすくないのは甲状腺機能の変化を関連し ていることが充分考皃られる。すなおち，降海時期に扎いて甲状腺機能の向上にともない降海のための活動

Table 3. Fatty acid composition of each fraction in the lipids of wild Masu almon parr (\%)

\begin{tabular}{|c|c|c|c|c|c|c|c|c|c|c|}
\hline \multirow{2}{*}{$\begin{array}{l}\text { Fatty } \\
\text { acid }\end{array}$} & \multicolumn{5}{|c|}{ Residual type } & \multicolumn{5}{|c|}{ Seaward migration type } \\
\hline & $\mathrm{SE}^{* 1}$ & $\mathrm{TG}^{* 1}$ & $\mathrm{DG}^{* 1}$ & $\mathrm{FFA}^{* 1}$ & $P^{* 1}$ & SE & & & & $\mathrm{PL}$ \\
\hline \multicolumn{11}{|c|}{ Saturated acid } \\
\hline $12: 0$ & 1.1 & 0.7 & 1.0 & 3.4 & $\operatorname{tr}^{* 2}$ & 2.9 & 0.7 & 0.6 & $\operatorname{tr}$ & 0.2 \\
\hline $14: 0$ & 1.2 & 3.7 & 2.1 & 3.7 & 1.0 & 0.8 & 3.5 & 1.9 & 2.2 & 0.8 \\
\hline $15: 0$ & 1.0 & 0.8 & 0.5 & 2.1 & 0.2 & 0.8 & 0.6 & 0.4 & 0.5 & 0.2 \\
\hline $16: 0$ & 27.5 & 19.4 & 17.6 & 28.6 & 25.5 & 25.5 & 21.5 & 18.6 & 29.8 & 24.6 \\
\hline $17: 0$ & 1.7 & 1.1 & 1.0 & 2.2 & 1.3 & 2.3 & 1.1 & 0.6 & 0.9 & 0.9 \\
\hline $18: 0$ & 4.4 & 5.6 & 4.5 & 7.8 & 8.4 & 4.8 & 5.5 & 5.1 & 3.8 & 7.3 \\
\hline Total & 36.9 & 31.3 & 26.7 & 47.8 & 36.4 & 37.1 & 32.9 & 27.5 & 37.2 & 33.8 \\
\hline \multicolumn{11}{|c|}{ Monoenoic acid } \\
\hline $14: 1$ & 0.7 & 2.1 & 1.2 & 1.8 & 0.1 & 0.4 & 1.4 & 0.9 & 0.8 & 0.2 \\
\hline $15: 1$ & 1.2 & 0.4 & 0.2 & 1.7 & 0.5 & 0.9 & 0.3 & 0.2 & 0.3 & 0.6 \\
\hline $16: 1$ & 12.6 & 15.8 & 13.7 & 9.2 & 6.5 & 9.6 & 14.1 & 11.8 & 11.2 & 4.7 \\
\hline $17: 1$ & 0.9 & 1.1 & 0.8 & 1.5 & 0.9 & 1.0 & 1.4 & 0.9 & 0.9 & 0.5 \\
\hline $18: 1$ & 20.4 & 27.5 & 30.6 & 15.9 & 17.8 & 17.3 & 25.5 & 27.4 & 19.9 & 15.4 \\
\hline 19: 1 & 0.7 & 0.3 & 0.3 & 0.2 & $\mathrm{tr}$ & 0.9 & 0.3 & 0.4 & 0.2 & 0.2 \\
\hline $20: 1$ & 2.5 & 1.7 & 1.6 & 1.3 & 0.5 & 1.9 & 1.1 & 1.6 & 0.7 & 0.6 \\
\hline $22: 1$ & - & - & - & - & - & - & - & - & - & - \\
\hline Total & 39.0 & 48.9 & 48.4 & 31.6 & 26.3 & 32.0 & 44.1 & 43.2 & 34.0 & 22.2 \\
\hline \multicolumn{11}{|c|}{ Polyenoic acid } \\
\hline $18: 2$ & 2.7 & 7.5 & 6.3 & 1.7 & 4.3 & 3.5 & 6.1 & 5.1 & 4.6 & 4.0 \\
\hline $18: 3$ & 1.8 & 5.1 & 3.9 & 0.9 & 2.5 & 3.3 & 7.8 & 5.1 & 4.2 & 3.4 \\
\hline $18: 4$ & - & 0.6 & tr & $\operatorname{tr}$ & 0.4 & - & 0.8 & 0.4 & 0.4 & 0.5 \\
\hline $20: 2$ & 1.7 & 1.1 & 0.9 & tr & 1.0 & 1.1 & 0.8 & 0.6 & 0.5 & 0.6 \\
\hline $20: 3$ & 0.6 & tr & 0.3 & tr & 0.5 & 0.6 & $\operatorname{tr}$ & 0.3 & tr & 0.4 \\
\hline $20: 4 \omega 6$ & 3.1 & 0.9 & 2.5 & 2.4 & 4.1 & 3.7 & 1.0 & 2.4 & 2.1 & 3.8 \\
\hline $20: 4 \omega 3$ & 0.8 & 0.4 & $\operatorname{tr}$ & 0.8 & 0.4 & 0.7 & 0.4 & 0.4 & 0.4 & 0.4 \\
\hline $20: 5$ & 7.6 & 2.4 & 5.2 & 5.4 & 5.6 & 9.3 & 3.5 & 5.9 & 9.0 & 8.1 \\
\hline $22: 4 \omega 6 ?$ & 1.0 & $\operatorname{tr}$ & $\operatorname{tr}$ & $\operatorname{tr}$ & 0.6 & 1.2 & $\operatorname{tr}$ & 0.7 & $\operatorname{tr}$ & 0.4 \\
\hline $22: 5 \omega 6$ & tr & tr & $\operatorname{tr}$ & $\operatorname{tr}$ & 1.1 & tr & tr & $\operatorname{tr}$ & $\operatorname{tr}$ & tr \\
\hline $22: 5 \omega 3$ & tr & 0.7 & 0.7 & 1.1 & 2.0 & $\operatorname{tr}$ & 1.0 & 1.8 & 0.9 & 2.4 \\
\hline $22: 6$ & 4.8 & 1.1 & 5.1 & 5.4 & 14.8 & 7.4 & 1.6 & 6.6 & 6.7 & 19.0 \\
\hline Unknown & - & - & - & 2.9 & - & - & - & - & - & 1.0 \\
\hline Total & 24.1 & 19.8 & 24.9 & 20.6 & 37.3 & 30.8 & 23.0 & 29.3 & 28.8 & 44.0 \\
\hline
\end{tabular}


性が增大し，そのだめのエネルギー源として脂質が消費され成分中トリグリセリドが利用されるものと思わ れる。な抗この際にはトリグリセリドの加水分解に関与するリペーゼの活性が高主ることが子想され，この 作用に甲状腺刺激ホルモンが関保していることも考えられる81。

またトリグリセりドの減少度については天然魚と養殖魚の間に差異があり，養殖魚の方がトリグリセりド 量の低下の度合が大きかった。この差異は生活環境のちがいによるものとも考えられるが，変態の過程から

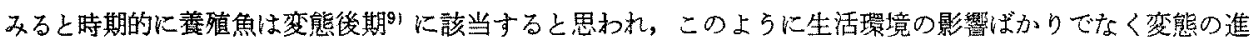
行度の差異が脂筫の代謝にも影響していることが推察される。

脂質成分中炭化水索拉よびステリンについては GLCによる分析で成分の確認をおこなった。 Fig. 2 に天 然魚河川残留型についてのクロマトグラムを示しだ。この結果は他の試料魚についても同様であって，炭化 水素はスクワレンが主要成分であり，ステリンエステル，遊離ステリン中のステリンはコレステリンが主要 成分であった。

脂肪酸組成の相異 天然魚および盖殖魚筋肉脂質成分中の脂肪酸組成を Table 3,4 に示した。各成分中

Table 4. Fatty acid composition of each fraction in the lipids of cultivated Masu salmon parr (\%)

\begin{tabular}{|c|c|c|c|c|c|c|c|c|}
\hline \multirow{2}{*}{ Fatty acid } & \multirow{2}{*}{ TG*1 } & \multicolumn{2}{|c|}{$\begin{array}{l}\text { Residual type } \\
\text { DG }^{* 1} \text { FFA }\end{array}$} & \multirow{2}{*}{$\mathrm{PL}^{* 1}$} & \multicolumn{4}{|c|}{ Seaward migration type } \\
\hline \multirow{2}{*}{\multicolumn{9}{|c|}{ Saturated acid }} \\
\hline & & & & & & & & \\
\hline $12: 0$ & $\operatorname{tr} * 2$ & $\operatorname{tr}$ & $\operatorname{tr}$ & - & tr & $\operatorname{tr}$ & tr & - \\
\hline $14: 0$ & 2.6 & 3.1 & 2.6 & 1.6 & 2.1 & 3.1 & 2.7 & 1.6 \\
\hline $15: 0$ & 0.2 & 0.4 & 0.2 & 0.3 & 0.3 & 0.7 & 0.4 & 0.6 \\
\hline $16: 0$ & 21.5 & 18.5 & 25.2 & 39.8 & 14.6 & 31.7 & 34.0 & 44.6 \\
\hline $17: 0$ & 0.2 & 0.4 & $\operatorname{tr}$ & 0.6 & 0.4 & 0.6 & 0.4 & 1.3 \\
\hline 18:0 & 4.4 & 3.8 & 3.1 & 5.7 & 3.9 & 5.9 & 1.8 & 5.8 \\
\hline Total & 28.9 & 26.2 & 31.1 & 48.0 & 21.3 & 42.0 & 39.3 & 53.9 \\
\hline \multicolumn{9}{|l|}{ Monoenoic acid } \\
\hline $14: 1$ & 0.1 & 0.2 & 0.2 & $\operatorname{tr}$ & 0.2 & 0.4 & tr & - \\
\hline $15: 1$ & tr & 0.3 & $\operatorname{tr}$ & 0.5 & tr & 0.6 & $\operatorname{tr}$ & 1.2 \\
\hline $16: 1$ & 10.0 & 11.9 & 7.6 & 4.6 & 7.5 & 7.2 & 5.2 & 3.3 \\
\hline 17: 1 & 0.3 & 0.6 & $\operatorname{tr}$ & 0.3 & 0.4 & 0.7 & 0.3 & - \\
\hline $18: 1$ & 35.8 & 35.1 & 26.8 & 19.6 & 33.3 & 23.1 & 12.9 & 14.7 \\
\hline $19: 1$ & - & - & - & - & - & - & - & - \\
\hline $20: 1$ & 2.9 & 3.0 & 1.8 & $\operatorname{tr}$ & 5.3 & 2.6 & $\operatorname{tr}$ & - \\
\hline $22: 1$ & 0.9 & 0.7 & $\operatorname{tr}$ & $\operatorname{tr}$ & 1.9 & $\operatorname{tr}$ & - & - \\
\hline Total & 50.0 & 51.8 & 36.4 & 25.0 & 48.6 & 34.6 & 18.4 & 19.2 \\
\hline \multicolumn{9}{|l|}{ Polyenoic acid } \\
\hline $18: 2$ & 16.4 & 15.3 & 17.8 & 8.0 & 24.1 & 13.3 & 19.8 & 5.9 \\
\hline $18: 3$ & 1.0 & 1.2 & 0.7 & - & 1.9 & 1.3 & 2.0 & - \\
\hline $18: 4$ & $\operatorname{tr}$ & - & - & - & $\operatorname{tr}$ & - & - & - \\
\hline $20: 2$ & 0.5 & 0.5 & $\operatorname{tr}$ & $\operatorname{tr}$ & 0.6 & $\mathrm{tr}$ & $\operatorname{tr}$ & 0.3 \\
\hline $20: 3$ & $\operatorname{tr}$ & $\operatorname{tr}$ & $\operatorname{tr}$ & $\operatorname{tr}$ & $\operatorname{tr}$ & $\operatorname{tr}$ & $\operatorname{tr}$ & - \\
\hline $20: 4 \omega 6$ & $\operatorname{tr}$ & 0.5 & 1.0 & 1.3 & 0.5 & 0.8 & 1.9 & 2.2 \\
\hline $20: 4 \omega 3$ & $\operatorname{tr}$ & 0.3 & $\operatorname{tr}$ & $\operatorname{tr}$ & $\operatorname{tr}$ & $\operatorname{tr}$ & - & - \\
\hline $20: 5$ & 0.7 & 0.9 & 2.7 & 2.8 & 0.7 & 2.3 & 4.3 & 4.2 \\
\hline $22: 4 \omega 6 ?$ & - & - & - & - & - & - & - & - \\
\hline $22: 5 \omega 6$ & - & - & - & - & - & - & - & - \\
\hline $22: 5 \omega 3$ & $\operatorname{tr}$ & $\operatorname{tr}$ & $\operatorname{tr}$ & $\mathrm{tr}$ & $\operatorname{tr}$ & $\operatorname{tr}$ & $\operatorname{tr}$ & $\operatorname{tr}$ \\
\hline $22: 6$ & 2.4 & 3.3 & 10.2 & 14.9 & 2.2 & 5.7 & 14.2 & 14.3 \\
\hline Total & 21.0 & 22.0 & 32.4 & 27.0 & 30.0 & 23.4 & 42.2 & 26.9 \\
\hline
\end{tabular}

*! TG-Triglycerides, DG-Diglycerides, FFA-Free fatty acids, PL-Phospholipids

*2 Trace 
の脂肪酸組成をみると天然魚, 養殖魚いずれの場合も河川残留型，降海型に関係なくトリグリセりドとジグ リ七りドの脂肪酸組成は類似し，亲た遊離脂肪酸とリン脂質の脂肪酸組成が頻似している。飽和酸は一般に 澱離脂肪酸, リン脂質に多く、モノエン酸はトリグリセリド，ジグリセリドに多い傾向が認められた。ポり エン酸のらち 18:2, 18:3 はトリダリセリドルジグリりドで含量が多く, その他のポりエン酸は遊離脂肪 酸、リン脂質の方で含量が多かった。

養殖急に㧊いて遊離脂肪酸中の $20: 5,22: 6$ の含量が多く, リン脂質中の含量と比較的類似していること から遊離脂肪酸はりン脂質の加水分解飞上る産物之も考之ら机るが，天然魚の堤合には遊離脂肪酸中の 22:6 量はりン脂質におけりよりもすくない。をた他の脂肪酸, たとえば荃殖魚の場合 $18: 2$ の含量は遊離脂肪酸 とリン脂質とに差珙が認められることから，かならずしも遊離脂肪酸はリン脂質の加水分解産物のみでなく グリセリド由来の脂肪酸代謝過程炕格ける中間物質としての脂肪酸も存在していることが考えられる。

なお然魚におけるステリンエステル中の脂肪酸組成はダりセりド中の脂肪酸組成とことなりポりェン酸 中で 18:2,18:3の含量がすくなく，逆に 20:5，22:6 が多い傾向を示し，遊離脂肪酸やりン脂質中の組成 と此輍的類似していた。

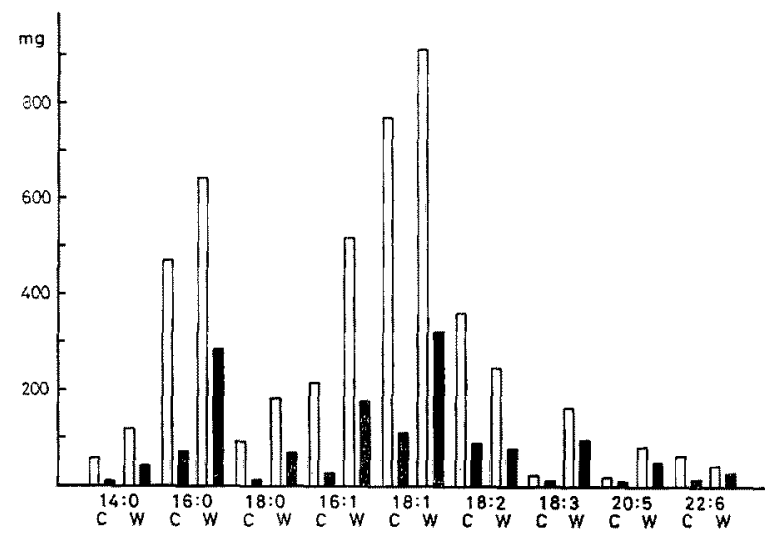

Fig. 3. Differences in the contents of major fatty acids in neutral lipids of residual type and seaward migration type of Masu salmon parr $(\mathrm{mg} / 100 \mathrm{~g}$ of flesh).

C-Cultivated fish, W-Wild fish, $\square-$ Residual type, - - Seaward migration type

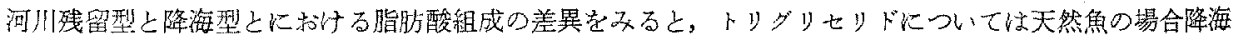
型の方が 16:1,18:1の雨者とも含量がすくなく，20:5，22:6などのポリエン酸量はやや多かった。また養 殖魚に拟いては 16:0 が河川残留型 $21.5 \%$ に対し降海型は $14.6 \%$ と降海型ですくない值を示し，さらに 16:1,18:1なども天然魚におけるのと同様すくなかった。天然魚拉よび養殖魚に共通して隆海型では総モ〉 エン酸含量がすくなく，逆に総ポリエン酸含量が多かった。この傾向はジがりセりドにおいても同棣であっ た。遊離脂肪酸の組成は天然魚においてもノエン酸含量は降海型で多いが，養殖魚の場合にはさきのトリグ リセりド, ジグリセりドと同样降海型の方がーくなく, ポリエン酸含量は天然魚, 養殖魚とも降海型で多か

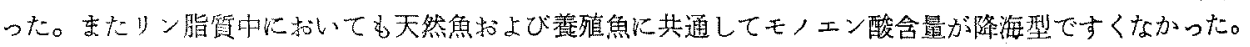

このよ5に各脂留成分において河川残留型と降海型の脂肪酸組成に差異のあることがわかったが，さらに

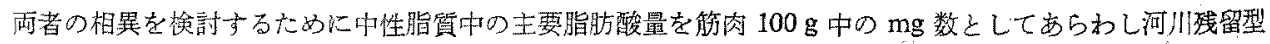
と降海型を比較した結果をFig. 3 に示した。いずれの脂肪酸も降海型においてすくない值を示したが，養殖

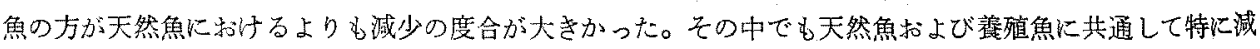
少の度合の大きい脂肪酸は 16:1，18:1 であり，降海型汇括ける 16: 1 量は天然魚では河川残留型が $517 \mathrm{mg}$ に対し $177 \mathrm{mg}$ と $34 \%$ まで, 隻殖魚では河川残留型 $215 \mathrm{mg}$ に対し $28 \mathrm{mg}$ と $13 \%$ まで減少しており, 
た 18:1 量は天然魚で河川残留型 $908 \mathrm{mg}$ に対し $322 \mathrm{mg}$ と $35 \%$ むで, 恙殖魚では河川残留型が $767 \mathrm{mg}$ に 対し $113 \mathrm{mg}$ と $15 \%$ まで低下している。さきに降海型において脂貿含量が河川残留型上りすくなくまた 脂質成分中でトリグリセりド量も寸くない値を示すことは隆海型サクラマス幼筧が降海のためのエネルギー 源としてトリグリセりドを消贅した結果と考察したが，その中で利用される脂肪酸としてはこのよらな綃果 からみると16:1，18:1などのモノェン酸が主体であると考克られる。

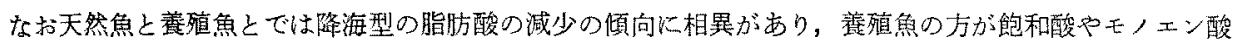
に加えてポリェン酸においても減少の度合が大きい。このような結果についてはすでにのべたごとく变態の

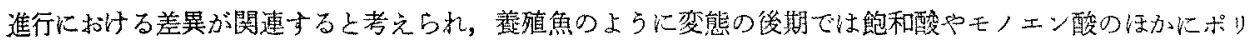
エン酸などもェネルギー源としての利用度が高昰るものと推定される。

\section{要 約}

天然㧍よび着殖サクラマス幼魚を試料として，降海時期に斿ける河川残留型と降海型の等奐脂質の脂質租 成と脂肪酸組成の相異を調べ次の結果を得た。

1）笳内部の脂質含量は降海型の方がすくなく，河川残留型の $1 / 2$ 以下であった。

2）降海型と河川残留型とにおける脂質組成を比較すると，降海型の方が河川残留型上りトリグリセりド 量がすくなく，逆にりン脂質，遊離ステリン量が多かった。しかしリン脂質量を筋肉 $100 \mathrm{~g}$ 中の $\mathrm{mg}$ 数と してあらわし比較すると，降海型と河川残留型との間仁大きな差翼はなかった。

3) 主要脂肪酸量を筋肉 $100 \mathrm{~g}$ 中の $\mathrm{mg}$ 数としてあらわし両型を比較すると，降海型ではいずれの脂肪酸 もすくない値を示すが，その中でも $16: 1,18: 1$ などの脂肪酸の減少の度合が大きかった。

このような結果から，降海時期においては降海型サクラマス幼魚筋肉中の脂筫（主にトリグリセりド）が エネルギー源として消費される割合も高るるものと考えられ，脂肪酸中主に 16:1,18:1などのモノェン酸

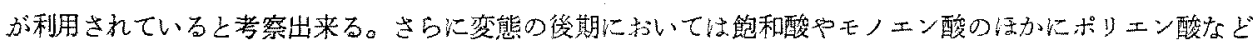
も消費されることが推定された。

本研究を抢こならにあたり北海道大学水産学部 久保達即助教授, 東北区水産研究所小坂 淳氏仁武料 入手以ついての御援助と多大な御助言をいただいた。深く感謝の意を表する。

\section{文献}

1) 太田 亭・山田 実：北大水産器報，22, 151-158 (1971).

2) 太田亭・山田 実: 本誌, 40, 699-706 (1974).

3) E. G. BLIGH and W. J. DYER: Can. J. Biochem. Physiol., 37, $911-917$ (1959).

4) J. N. Roehm, D. J. Lee, J. H. Wales, S. D. Polityka and R. O. Sinnhuber: Lipids, 5, $80-84$ (1970).

5) 今井 陽：生物化学実駼法 VIII, 共立出版, 東京, 1967, pp. 157-182.

6) 野村 正: 化学の領域, 16, 345-352 (1962).

7) F. Takashima, T. Hibiya, Phan-Van Ngan and K. Aida: 本誌, 38, 43-49 (1972).

8）雕庭 弘・内藤周幸：脂䓄 2 , 第 1 版, 共立出版, 東京 1972, pp. 382-397.

9）久保達郎：北海道さけ・亦主子化場研報，19,25-32 (1965). 